\title{
Investigation of Relationships between Salt Stress, Potassium Application and Macro Element Uptake in Pepper Plant
}

\author{
Fikret Yasar (Corresponding author) \\ Van Yuzuncu Yil University, Faculty of Agriculture, Department of Horticulture, Van, Turkey \\ E-mail: fyasar@yyu.edu.tr \\ Omer Oztas \\ Van Yuzuncu Yil University, Graduate School of Natural and Applied Sciences, Van, Turkey \\ E-mail: omer_30@hotmail.com.tr \\ Ozlem Uzal \\ Van Yuzuncu Yil University, Faculty of Agriculture, Department of Horticulture, Van, Turkey \\ E-mail: ozlemuzal@yyu.edu.tr
}

The research was supported by BAP (The Scientific Research Projects Coordination Unit)

(Project no. FYL-2016-5513)

\begin{abstract}
This study was carried out to determine how plants behave in the uptake of macro nutrients by using different doses of potassium $\left(\mathrm{K}^{+}\right)$together with salt to understand how to recover from stress. Demre Sivri pepper variety was used in the study. The study was carried out in a controlled climate room for 16/8 hours with light / dark photoperiod, $25^{\circ} \mathrm{C}$ and $70 \%$ humid climate. Seedlings formed after germination of seeds transformed in pumice were taken to hydroponic culture after having 2 true leaves. Hoagland nutrition solution was used in hydroponic culture. 116, 136, 156 and $176 \mathrm{ppm}$ potassium $\left(\mathrm{K}^{+}\right)$ was used in the present Hoagland solution. In addition, $100 \mathrm{mM} \mathrm{NaCl}$ salt was applied to the plants. Sampling for measurements and analyzes was performed on day 20 of salt administration. In these samples, total plant weight and potassium $\left(\mathrm{K}^{+}\right)$, calcium $\left(\mathrm{Ca}^{+2}\right)$, magnesium $\left(\mathrm{Mg}^{+2}\right)$ element contents were determined. At the same time, $\mathrm{Na}^{+}$and $\mathrm{Cl}^{-}$uptake were also investigated because of the salt application. The results showed that $\mathrm{K}^{+}$doses of $156 \mathrm{ppm}$ and $176 \mathrm{ppm}$ were effective in ion uptake and reduction of harmful effects of salt.
\end{abstract}

Keywords: Pepper, Ion accumulation, Potassium doses, Salt stress

DOI: $10.7176 / J S T R / 5-11-03$

\begin{abstract}
1. Introduction
In plants exposed to salt stress, the decrease in yield is due to the direct toxic effect of sodium (Na) and similar cations in the environment. Reaching high levels of salt stress $\mathrm{Na}$ and $\mathrm{Cl}, \mathrm{K}, \mathrm{Ca}, \mathrm{N}$ uptake of plants by reducing the ion balance can cause deterioration (Gunes et al. 1994; Inal et al., 1995). There is a positive effect between the amount of $\mathrm{K}$ found in the leaf of the plant and the increase of plant resistance under saline conditions and high $\mathrm{K}^{+} / \mathrm{Na}^{+}$ratio is proportional to salt (Sherif et al., 1998). In case of potassium or calcium deficiency, osmoregulation in the plant is disrupted and enzyme activation is inhibited and metabolism is negatively affected. In such a case, an external potassium supplement should be made. In this way, the plant is affected by stress is reduced (Kaya et al., 2006).

Yaşar et al., (2006a) found that under the stress of eggplant, two sensitive and two tolerant varieties used in the study of sensitive genotypes were found to be higher $\mathrm{Na}$ and $\mathrm{Cl}$ ion accumulation, $\mathrm{K}$ and $\mathrm{Ca}$ amounts of these genotypes have reported a decrease. Similar results were obtained from the studies of Yaşar et al. (2006b; 2013), Üzal, (2009), Üzal and Yıldız, (2014).

Potassium intake in salty soil conditions also decreases due to water stress and water insufficiency, potassium plays an important role in alternative nutrition (Kemmler and Kraus, 1971). There is a positive
\end{abstract}

13 | $\mathrm{P}$ a g e

www.iiste.org 
correlation between the amount of potassium present in the plant leaves and the increase in plant resistance under saline conditions and high $\mathrm{K}^{+} / \mathrm{Na}^{+}$ratios are directly proportional to salt resistance (Sherif et al., 1998).

The aim of this study was to determine the relationship between $\mathrm{K}$ uptake, macro element uptake and Na, $\mathrm{Cl}$ accumulation in stressed plants by applying different doses of $\mathrm{K}$ in nutrient medium together with salt stress to Demre peppers.

\section{Material and Method}

This research was carried out in the climatic room of Van Yuzuncu Y1l University, Faculty of Agriculture, Department of Horticulture, Physiology Laboratory. Demre Sivri Pepper variety was used in the study. The experiment was carried out in a split air-conditioned climate room with normal atmosphere and water culture. The main objective of the experiment is to ensure that the effects of salt stress occur as normal under normal conditions. In this way, the stress level to which the plants are exposed in the outdoor environment will be measured with the least margin of error and the results obtained as a result of the application of the results obtained will show greater consistency with the study results.

Table 1. Contents of the nutrient solution used (ppm).

\begin{tabular}{lccccc}
\hline Elements & $\begin{array}{c}\text { App. 1 } \\
\text { Control } \\
(\mathrm{ppm})\end{array}$ & $\begin{array}{c}\mathrm{App} .2 \\
\mathrm{~K} 1+\mathrm{NaCl} \\
(\mathrm{ppm})\end{array}$ & $\begin{array}{c}\text { App. 3 } \\
\mathrm{K} 2+\mathrm{NaCl} \\
(\mathrm{ppm})\end{array}$ & $\begin{array}{c}\mathrm{App} .4 \\
\mathrm{~K} 3+\mathrm{NaCl} l \\
(\mathrm{ppm})\end{array}$ & $\begin{array}{c}\text { App. 5+ NaCl } \\
\text { Kpm) }\end{array}$ \\
\hline Nitrogen (N) & 186 & 186 & 186 & 186 & 186 \\
Phosphorus (P) & 31 & 31 & 31 & 31 & 31 \\
Potassium (K) & $\mathbf{1 3 6}$ & $\mathbf{1 1 6}$ & $\mathbf{1 3 6}$ & $\mathbf{1 5 6}$ & $\mathbf{1 7 6}$ \\
Magnesium (Mg) & 49.28 & 49.28 & 49.28 & 49.28 & 49.28 \\
Calcium (Ca) & 200 & 200 & 200 & 200 & 200 \\
Sulfur (S) & 66 & 66 & 66 & 66 & 66 \\
Iron (Fe) & 3.3 & 3.3 & 3.3 & 3.3 & 3.3 \\
Manganese (Mn) & 0.031 & 0.031 & 0.031 & 0.031 & 0.031 \\
Boron (B) & 0.205 & 0.205 & 0.205 & 0.205 & 0.205 \\
Copper(Cu) & 0.015 & 0.015 & 0.015 & 0.015 & 0.015 \\
Zinc (Zn) & 0.023 & 0.023 & 0.023 & 0.023 & 0.023 \\
\hline
\end{tabular}

The nutrient solution used was prepared according to (Hoagland and Arnon, 1938).

In the study, first of all, pepper seeds were sown in $40 \times 25 \times 5 \mathrm{~cm}$ plastic germination cups filled with pumice sieved and then watered with fountain water. The bottom surface of the germination vessels has 9 holes with a diameter of $0.5 \mathrm{~cm}$ and the irrigation water is used by the plants. After the pumice was thoroughly wetted and the irrigation water was used by the plants, the germination pots were placed in the climate room with $25 \pm 2^{\circ} \mathrm{C}$ temperature $70 \%$ humidity, covered with $\mathrm{A} 4$ paper and the containers were regularly checked and the pumice was continued to be irrigated with tap water. For the better development of the seedlings, the cotyledon leaves coming horizontally and the first true leaves (3-4) began to be seen, irrigation was started with Hoagland nutrient solution. (Hoagland and Arnon, 1938).

\subsection{Mineral element analysis}

Three leaves from tip to downward were taken and they were kept in deep freezer at $-84^{\circ} \mathrm{C}$. About 200 g samples were taken from the deep freezer and samples were supplemented with $10 \mathrm{ml} 0.1 \mathrm{~N} \mathrm{HNO}_{3}$ (Nitric acid). They were then kept in plastic boxes at dark and room temperature for a week. The samples were shaken in the shaker for 24 hours and $\mathrm{Na}^{+}, \mathrm{K}^{+}, \mathrm{Ca}^{+2}, \mathrm{Mg}^{+2}$ contents were determinated in Atomic Absorption Device according to Kacar (1994). $\mathrm{Cl}^{-}$ion was measured by an automated chloridometer (Buchler - Cotlove chloridometer) which was analyzed by colorimetric amperometric titration with silver ions. At the end of these measurements, the amount of ions in the fresh leaf sample was determined as $\mu \mathrm{g} / \mathrm{mg}$ fresh weight (Taleisnik et al., 1997).

All results were the means of three replicates, and each replicate consisted of fifteen plants. Data were analzsed statistically and treatment means were separated by Duncan's Multiple Range Test using SAS (1985) software. Experiments were conducted in complete randomized plots design with 3 replications. Resultant data were subjected to statistical analyses with SAS software (SAS Institute, 1985). 


\section{Results}

At the end of the application of $100 \mathrm{mM} \mathrm{NaCl}$ salt stress for 20 days, the data obtained in terms of the amount of $\mathrm{Na}, \mathrm{K}, \mathrm{K} / \mathrm{Na}, \mathrm{Cl}, \mathrm{Ca}$ and $\mathrm{Mg}$ ion in the leaf is given in Table 2.

Table 2. Ion deposits in leaf parts after application ( $\mu \mathrm{g} / \mathrm{mg}$ F.W.)

\begin{tabular}{lrrrrrc}
\hline Application & $\mathrm{Na}^{+}$ & $\mathrm{K}^{+}$ & $\mathrm{K}^{+} / \mathrm{Na}^{+}$ & $\mathrm{Cl}^{-}$ & $\mathrm{Ca}^{+2}$ & $\mathrm{Mg}^{+}$ \\
\hline Control & $0.482 \mathrm{D}$ & $26.616 \mathrm{~A}$ & $17,960 \mathrm{~A}$ & $0.267 \mathrm{D}$ & $5.455 \mathrm{~A}$ & $25.159 \mathrm{~B}$ \\
$\mathrm{~K} 1+$ Salt & $9.544 \mathrm{~A}$ & $11.009 \mathrm{C}$ & $1,153 \mathrm{D}$ & $6.420 \mathrm{~A}$ & $3.049 \mathrm{~B}$ & $13.782 \mathrm{C}$ \\
$\mathrm{K} 2+$ Salt & $4.585 \mathrm{~B}$ & $17.136 \mathrm{~B}$ & $3,737 \mathrm{C}$ & $4.297 \mathrm{~B}$ & $2.747 \mathrm{~B}$ & $14.500 \mathrm{C}$ \\
$\mathrm{K} 3+$ Salt & $3.680 \mathrm{C}$ & $25.217 \mathrm{~A}$ & $6,852 \mathrm{~B}$ & $3.842 \mathrm{~B}$ & $5.888 \mathrm{~A}$ & $26.188 \mathrm{~B}$ \\
K4+ Salt & $3.625 \mathrm{C}$ & $25.174 \mathrm{~A}$ & $6,945 \mathrm{~B}$ & $2.215 \mathrm{C}$ & $3.350 \mathrm{~B}$ & $28.927 \mathrm{~A}$ \\
\hline
\end{tabular}

The difference between the means taking the same capital letter in the same column is insignificant according to $\mathrm{P} \leq 0.05$. (F.W

$$
\text { Fresh Weight) }
$$

$\mathrm{Na}$ deposition in the leaves of salt treated plants decreased due to the increase in potassium doses. The highest $\mathrm{Na}$ accumulation was observed in $\mathrm{K} 1+$ Salt application while the lowest $\mathrm{Na}$ accumulation was observed in $\mathrm{K} 4+$ Salt application.

The accumulation of $\mathrm{K}$ in the leaves of the plants treated with salt increased due to the increase of $\mathrm{K}$ doses. Similar to the control, the highest $\mathrm{K}$ accumulation was observed in the leaves at $\mathrm{K} 4+$ salt dose. It was observed that there were differences between the doses in terms of $\mathrm{K} / \mathrm{Na}$ ratio in the leaves of the plants treated with salt. As the potassium dose increased, $\mathrm{K} / \mathrm{Na}$ ratio in the leaves increased. After the control application, the highest $\mathrm{K} / \mathrm{Na}$ ratio occurred in $\mathrm{K} 4+$ Salt application.

In terms of $\mathrm{Cl}$ accumulation in the leaves of the plants treated with salt, the difference between the other treatments except the control was found to be statistically significant. There was an increase in $\mathrm{Cl}$ ion accumulation in other applications compared to the control group. $\mathrm{Cl}$ accumulation in the leaf organ increased compared to control. The highest increase was seen in K1 + Salt application where the lowest potassium dose was applied, while the lowest $\mathrm{Cl}$ accumulation was observed in the application of $\mathrm{K} 4+$ Salt where the highest potassium dose was observed. As the $\mathrm{K}$ dose increased, the accumulation of $\mathrm{Cl}$ in the leaf decreased.

It was seen that there were differences between the applications in terms of Ca accumulation in the leaves in the salt treated plants. Except for K3 + Salt application, Ca deposition decreased in leaves compared to control. K3 + Salt application was in the same statistical value range as the control, while other applications were in the same range.

In the study of salt application, it was found that there are differences in $\mathrm{Mg}^{+}$accumulation in leaves. There was a decrease in low doses of potassium before leaf control, there was an increase in high doses.

\section{Discussion and Conclusion}

On the 20th day of application of different $\mathrm{K}$ doses with $100 \mathrm{mM} \mathrm{NaCl}$, pepper plants had the highest decrease in total plant weight compared to the control at the 1 st dose of potassium. Yasar et al. (2006a, 2006b, 2008, 2013, 2016) showed that total plant weights were an important parameter in determining the response to salt stress. In addition, salt has had a negative impact on other plant growth parameters. The first dose of potassium did not have the effect of reducing the negative effect of the salt, while the second, third and fourth doses were those which were positively effective, respectively. The results of our study showed that the growth and development of plants are reduced due to the slowing of the respiration of plants in saline environments. Hormonal disorders occur in the plant as a result of the deterioration of the respiratory system, that is, the decrease in stomal mobility, and consequently decrease in the photosynthesis of the plant, thus decrease in the assimilate formation and decrease in the growth and development of all these (Çakırlar and Topçuoğlu, 1985; Yasar, 2003; 2007).

One of the most important reasons for the decrease in the growth of salt stressed pepper plants is the amount of $\mathrm{Na}$ they accumulate in their bodies in excess and toxic levels. However, in potassium applications, $\mathrm{Na}$ accumulation in leaves decreased as $\mathrm{K}$ dose increased. Especially in the $\mathrm{K} 4$ dose, the decrease in $\mathrm{Na}$ accumulation was more pronounced than the $\mathrm{K} 1 \mathrm{dose}$. Ion regulation is one of the most prominent features in determining the tolerance of plants to salt. Plants with high $\mathrm{NaCl}$ salt concentration receive excessive $\mathrm{Na}$ ions. The uptake of $\mathrm{K}$ ion, which is very similar to sodium ion due to its ionic diameters and electrical charges, is prevented. In contrast, higher $\mathrm{K}$ and $\mathrm{Ca}$ uptake during the uptake of low $\mathrm{Na}$ and $\mathrm{Cl}$ ions in salt conditions of some plant genotypes is a key mechanism of tolerance. Tissues of plants with better tolerance to salt stress are generally capable of producing a higher $\mathrm{K} / \mathrm{Na}$ ratio. Many studies (eggplant, bean, melon, tomato and pepper) to determine the tolerance to salt stress in

15 | P a g e 
plants, $\mathrm{K} / \mathrm{Na}$ and $\mathrm{Ca} / \mathrm{Na}$ ratios in different plant organs and the determination of $\mathrm{Na}^{+}$concentrations in tissues appear as an important parameter (Marschner, 1995; Daşgan et al., 2002; Yaşar, 2003; Zeng et al., 2003; Aktaş et al., 2006; Kuşvuran et al., 2007; Daşgan and Koç, 2009). Due to its very similarity due to its ionic diameters and electrical charges, $\mathrm{K}$ and $\mathrm{Na}$ ions significantly reduced $\mathrm{Na}$ uptake by showing the effect of $\mathrm{K}$ doses in saline environment in order to convert the advantage of $\mathrm{K}$ and $\mathrm{Na}$ ions in favor of $\mathrm{K}$.

\section{References}

Aktas, H., Abak. K., Cakmak, I. (2006). Genotypic Variation in The Response of Pepper to Salinity. Scientia Hort. 110: 260-266.

Çakırlar, H., Topçuoğlu, S. F. (1985). Stress Terminology Desertification World and The Case of Turkey. Atatürk University Environmental Problems Research Center

Daşgan, H. Y., Aktaş, H., Abak., K, Çakmak, İ. (2002). Determination of Screening Techniques to Salinity Tomatoes and Investigation of Genotype Responses. Plant, 163:695-703.

Daşgan, H.Y., Koç, S. (2009). Evaluation of Salt Tolerance in Common Bean Genotypes by Ion Regulation and Searching for Screening Parameters. Journal of Food, Agriculture Environment, 7(2): 363-372.

Güneş, A., Post, W. H. K., Kirkby, E. A., Aktaş, M. (1994). Influence of partial replacement on nitrate by amino acid nitrogen or urea in the nutrient medium on nitrate accumulation in NFT grown winter lettuce. Journal of Plant Nutrition, 17 (11); 1929-1938.

Hoagland, D.R., Arnon, D.I. (1938). The Water Culture Method for Growing Plants Without Soil. Circular California Agricultural Experiment Station, 1; 347-461.

Inal, A., Güneş, A., Aktaş, M. (1995). Effects of chloride and partial substitution of reduced forms of nitrogen for nitrate in nutrient solution of the nitrate, total nitrogen and chlorine contents of onion. Journal of plant nutrition, 18:2219-2227.

Kacar, B. (1994). Chemical analysis of plant and soil analysis. Ankara Univ. Faculty of Agriculture Publication No. 3 Ankara.

Kaya, C., Tuna., L., Higgs D. (2006). Effect of silicon on plant growth and mineral nutrition of maize grown under water stress conditions. Journal of Plant Nutrition, 29: 8, 1469-1480.

Kemmler, C., Krauss, A. (1971). K and stress tolerance. Bünthe of Agriculture Research station of Kali und Salz A. C. Bünteweg 8, D-3000 Hannover.

Kuşvuran, Ş., Ellialtığlu, S., Abak, K., Yaşar, F. (2007). Responses of Some Melon (Cucumis sp.) Genotypes to Salt Stress. Journal of Agricultural Sciences, 13 (4): 395-404.

Marschner, H. (1995). Mineral Nutrition of Higher Plants. Acad. Press, London.889 pp.

SAS-INSTITUE, (1985). Sas/ StateUser's Guide 6.03 ed. SAS. Ins. Cary. N. C.

Sherif, M. A., El-Beshbeshy, T.R., Richter, C. (1998). Response of some Egyptian varieties of wheat (Triticum aestivum L.) to salt stress through potassium application. Bulletin of Faculty of Agriculture, University of Cairo 49: 129-151.

Taleisnik, E., Peyran, G., Arias, C. (1997). Respose of Chloris gayana Cultivars to Salinity. 1. Germination and Early Vegetatif Growth. Trop. Grassl. 31: 232-240. 
Üzal, Ö. (2009). Effects of Jasmonic Acid on Plant Growth and Antioxidant Enzyme Activities in Some Strawberry Cultivars Grown Under Salt Stress. (PhD Thesis). Centenary University. Graduate School of Natural and Applied Sciences, Van.

Üzal,Ö., Yıldı, K. (2014). Reactions to Salt Stress of Some Strawberry (Fragaria x ananassa L.) Cultivars. Yuzuncu Y1l University Journal of Agricultural Sciences, 24, 159-167.

Yasar, F. (2003). Investigation of some antioxidant enzyme activities in eggplant genotypes grown under salt stress in vivo and in vitro. Yuzuncu Yil University, Institute of Natural and Applied Sciences, PhD Thesis, pp139, Van-Turkey.

Yasar, F. (2007). Effects of salt stres on ion and lipid peroxidation content in green beans genotypes. Asian Journal of Chemistry, 19(2): 1165-1169.

Yaşar F., Ellialtioglu S., Kusvuran S. (2006a). Ion and lipid peroxide content in sensitive and tolerant eggplant callus cultured under salt stress, European Journal of Horticultural Science, vol.71, pp.169-172.

Yaşar F., Üzal Ö., Tufenkci S., Yildiz K. (2006b). Ion accumulation in different organs of green bean genotypes grown under salt stress, Plant Soil and Environment, vol.52, pp.476-480.

Yasar, F., Ellialtıoğlu S., Yıldız, K. (2008). Effect of Salt Stress on Antioxidant Defense Systems, Lipid Peroxidation, and Chlorophyll Content in Green Bean, Russian Journal of Plant Physiology, $55,782-786$.

Yaşar, F., Üzal, Ö., Yaşar, Ö. (2013). Identification of lon Accumulation and Distribution Mechanisms in Watermelon Seedling (Citrullus lanatus (Thunb) Mansf.) Grown Under Salt Stress. Yuzuncu Y1l Universitesi Ziraat Fakultesi Tarım Bilimleri Dergisi., 23. 209-214.

Yasar, F., Uzal, O., Yasar, O. (2016). Antioxdant Enzyme Activities and Lipid Peroxidation Amount of Pea Varieties (Pisum sativum sp. Arvense L.) under Salt Stress. Fresenius Environmental Bulletin, 2, 37-42.

Zeng, L., Poss, J., Wilson, C., Draz, A.S.E., Grieve, C.M. (2003). Evaluation of Salt Tolerance in Rice Genotypes by Physiological Characters . Euphytica, 129: 281-292. 